
Brasileira 27: 189-195.

\title{
Combining ability in sweet pepper for resistance to powdery mildew
}

\author{
Cristina B Marchesan'; Arlete MT de Melo'; Maria Elisa AGZ Paterniani² \\ ${ }^{1}$ IAC-Centro de Horticultura, C. Postal 28, 13012-970 Campinas-SP; ${ }^{2}$ IAC-Centro de Gãos e Fibras; cbmarchesan@gmail.com; \\ Arlete@iac.sp.gov.br; elisa@iac.sp.gov.br
}

\begin{abstract}
With the increase of the production of pepper in protected environment, pathogens began to cause serious damages to producers such as Leveillula taurica (Lév.) Arn., fungus that causes powdery mildew. The systemic fungicides have not shown very satisfactory results. Thus, considering that protected cropping of pepper in Brazil is significant and growing, the incorporation of genes that confer resistance to powdery mildew is important for the maintenance of this cropping system. In this research, carried out in 2007 in Campinas, São Paulo State, Brazil, the agronomic performance and resistance to powdery mildew was determined by triple hybrids of sweet pepper through general and specific combining ability of their parents. For agronomic performance of the triple hybrid, it was evaluated the weight length and width average of the fruit, length and width ratio of the fruit and wall thickness. For severity of powdery mildew a scale of scores from 1 to 5 was used. For statistical and genetic analysis, it was adopted Griffing's method two, model I, adapted for partial diallel. The experimental design was completely randomized blocks, with 17 treatments, including ten experimental hybrids and seven parents, eight replications and four plants per plot. The additive effects were greater than the non-additive effects for all agronomic characters; 'P36-R' and 'Platero' were highlighted as good combiners; 'Quantum-R x HV-12', 'Rubia x HV-12' and 'P36-R x HV-12' presented the best specific combining ability; the mean square of the specific combining ability for the severity of the disease was significant indicating the importance of genes with dominant and epistatic effect; triple hybrids obtained by crosses with 'Quantum-R' and 'Rubia-R' had negative general combining ability and the best reactions to powdery mildew.
\end{abstract}

Keywords: Capsicum annuum L., Oidiopsis taurica (Lév) Arn., breeding, vegetables.

\section{RESUMO}

\section{Capacidade de combinação em pimentão para resistência a oídio}

Com o aumento do cultivo protegido de pimentão, patógenos como Leveillula taurica (Lév.) Arn., fungo causador do oídio, passaram a causar sérios prejuízos aos produtores. Os fungicidas sistêmicos não têm apresentado resultados muito satisfatórios. Assim, levando-se em conta que o cultivo protegido de pimentão no Brasil é importante e crescente, a incorporação de genes que conferem resistência ao oídio é relevante para a manutenção desse sistema de cultivo. Nesse trabalho, realizado em 2007 em Campinas-SP, determinou-se o potencial agronômico e de resistência a oídio de híbridos triplos de pimentão por meio da capacidade geral e específica de combinação dos genitores. Para determinar o desempenho agronômico dos híbridos triplos, avaliaram-se o peso, comprimento e largura média do fruto, relação entre comprimento e largura do fruto e espessura da polpa. Para a avaliação da severidade da doença utilizou-se escala de notas de 1 a 5 . Para as análises estatístico-genéticas, adotou-se o método dois, modelo I de Griffing, adaptado para dialelo parcial. O delineamento experimental utilizado foi o de blocos ao acaso, com 17 tratamentos, incluindo dez híbridos experimentais e sete genitores, oito repetições e quatro plantas por parcela. Os efeitos aditivos foram superiores aos efeitos nãoaditivos para todos os componentes agronômicos avaliados; 'P36-R' e 'Platero' destacaram-se como bons combinadores para os caracteres agronômicos avaliados; 'Quantum-R x HV-12', 'Rubia-R x HV-12' e 'P36-R x HV-12' apresentaram os maiores efeitos da capacidade específica de combinação para a maioria dos caracteres avaliados; o quadrado médio da capacidade específica de combinação significativo para a severidade da doença indicou a importância de genes com efeito de dominância e epistasia; híbridos triplos obtidos do cruzamento com 'Quantum-R' e 'Rubia-R' apresentaram capacidade geral de combinação negativa e as melhores reações de resistência ao oídio.

Palavras-chave: Capsicum annuum L., Oidiopsis taurica (Lév) Arn., melhoramento genético, hortaliças.

\section{(Recebido para publicação em 4 de junho de 2008; aceito em 8 de maio de 2009) (Received in June 4, 2008; accepted in May 8, 2009)}

$\mathrm{I}_{\mathrm{is}}^{\mathrm{n}}$ Brazil, the production of vegetables s the segment of agriculture that employs the most, being mainly grown by family farmers. In 2004 this segment occupied an area of approximately 776.8 thousand hectares with a production of 16,086 tons (Embrapa Hortaliças, 2008). The sweet pepper (Capsicum annuиm L.) is among the ten most important vegetables in the country (Maluf, 2001). The cultivation of sweet pepper occurs in almost all regions of Brazil, being mainly concentrated in the Southeast Region of the country in the States of
São Paulo, and Minas Gerais. In 2001, world production was approximately of 1.3 million hectares and Brazil gained 735.8 thousand reais (Brazilian currency) with the export of its products (Blat, 2004). In the country, about 1.5 million dollars is involved in the commercialization of seeds of hot and sweet peppers (Carvalho et al., 2003).

In 2007, the State of São Paulo was responsible for the commercialization of 54.6 thousand tons of sweet pepper, on an area of 1899 hectares, exceeding the production of 2006 in $9.6 \%$, which was
49.8 thousand tons of sweet pepper on an area of 2103 hectares. The production value for 2007 was 48.7 million reais, well above the result for 2006 of 30.7 million reais, representing an increase of $58.6 \%$ (IEA, 2008). Regarding the fruit quality, the difference in price of green pepper ExtraAA and Extra was $46 \%$ until August 2007, suggesting the consumer's preference for the aspects of appearance and size of the fruit (Agrianual, 2008). The price of mature sweet pepper, in general, is higher than the green, however, there are no available data 
distinguishing the production and marketing of these two segments.

The advent of the production of sweet pepper in protected cropping environment provided the conditions for the development of pathogens causing serious damages to producers, such as the Leveillula taurica (Lév.) Arn., one of the fungi that causes powdery mildew (Reis et al., 2004 ; Reis et al., 2007). On its anamorphic form it is known as Oidiopsis taurica and in this phase it is virulent (Boiteux et al., 1994; Bergamin Filho et al., 1995; Stadnik, 2001; Reis et al., 2004). They are easily recognized by forming colonies with powder aspect on the lower surface of the leaves of live plants. They are obligate biotrophic parasitic fungi, depending on the host for their development and reproduction (Bettiol et al., 1997; Reis et al., 2007). Reports show that L. taurica can infect several groups of plants, in addition to sweet pepper, many vegetables and ornamental (Stadnik, 2001; Reis et al., 2004; Reis et al., 2005, Reis et al., 2007).

Currently, $O$. taurica occurs in the main producing areas of sweet pepper in Brazil with protected cropping environment. The first symptoms are always observed in adult plants and older leaves, which are more susceptible to the pathogen (Souza \& Café Filho, 2003).

When powdery mildew started appearing in sweet pepper crops, farmers began to use systemic fungicides with specificity; however, it is not always efficient. Moreover, the abusive use may induce and promote the development of resistant breeds of the pathogen to the fungicide. Taking into account that the protected environment cultivation of sweet pepper in Brazil is significant and increasing, the incorporation of genes that confer resistance to powdery mildew is of great importance for the maintenance of the cropping system (Reis et al., 2005).

In a breeding program of vegetables the main goals are related to the introduction of genetic resistance to disease, productivity and product quality. The $\mathrm{F}_{1}$ hybrids have been the best strategy for an immediate increase of productivity and improvement in the quality of the fruit of sweet pepper, but not excluding the possibility of selecting superior inbred lines in segregating populations derived from $\mathrm{F}_{2}$ progenies or even from backcross (Stadnik, 2001).

One way to assess the genetic potential of the parents and hybrids is through diallel crosses evaluating the characters of interest. Its application is originated from the development of the concepts of general and specific combining ability, established by Sprague \& Tatum (1942).

The purpose of this study was to determine the agronomic performance and the resistance of triple hybrid of sweet peppers through general and specific combining ability of their parents.

\section{MATERIAL AND METHODS}

The experiments were conducted in a protected cropping environment, on the Horticulture Center of Instituto Agronômico (IAC) in Campinas, São Paulo, Brazil in 2007.

For the evaluation of the hybrids, the experimental design was randomized blocks, with 17 treatments, including ten experimental hybrid and seven parents, eight replications and four plants per plot. The cultivation was carried out in four beds with two lines of $30.6 \mathrm{~m}$ each. Spacing was $0.45 \times 0.5 \times 0.6 \mathrm{~m}$, respectively, between plants, lines and beds.

The triple hybrids were obtained through a partial diallel $5 \times 2$, in which five simple commercial hybrids of sweet pepper, susceptible to powdery mildew, with thick wall and large fruit ('QuantumR', 'Rubia-R', 'Platero', 'Margarita' and 'P36-R') were used as female parent and the genotypes 'HV-12' and '\#124', resistant to powdery mildew, were used as male parents. 'HV-12' is a dihaploid variety of sweet pepper obtained by anther culture from a cross between the pepper cultivar 'H3' and the sweet pepper 'Vânia', respectively resistant and susceptible to powdery mildew. The fruits are early fruiting, red long conical type and have no commercial value. '\#124' is a late fruiting pepper, with conical, small $(5$ to $10 \mathrm{~cm}$ ) and red fruits (Blat, 2004). The female and male parents were adopted as referential control for comparison purposes in the evaluation, monitoring the epidemic and characterization of the reaction of the genotypes to powdery mildew.

In the process of hybridization, the emasculation of the flower buds was done a day before the anthesis and the pollination of each flower was done on the next day. The fruits from the crosses were harvested mature and the $\mathrm{F}_{1}$ seeds were removed manually, packed in paper bags and identified by cross.

For obtaining and evaluating the triple hybrid, the plants were conducted in a staking system. The fertilizers were added based on the soil analysis recommendations, consisting of plantation fertilization in the role and coverage by using located fertirrigation system. For the preventive control of diseases and pests, products with the active ingredients were applied deltamethrin, imidacloprid, abamectin and difeconazole, the last one being used only in the stage of obtaining the triple hybrid.

The characters evaluated during the experiment were weight, length and width average of the fruit, length and width ratio of the fruit, wall thickness and severity of the disease.

The analysis of variance was done according to the statistical model $\mathrm{Y}_{\mathrm{ij}}=\mu$ $+\mathrm{t}_{\mathrm{i}}+\mathrm{b}_{\mathrm{j}}+\varepsilon_{\mathrm{ij}}$, where $\mathrm{Y}_{\mathrm{ij}}=$ the observation in the $\mathrm{j}^{\text {th }}$ block receiving the $\mathrm{i}^{\text {th }}$ treatment; $\mu=$ overall mean; $t_{i}=$ the fixed effect of the $i^{\text {th }}$ treatment (genotype) $b_{j}=$ the effect of the $\mathrm{j}^{\text {th }}$ block; $\varepsilon_{\mathrm{ij}}=$ random error. Data note of the disease were transformed into $\sqrt{\chi}$ and the averages were compared with each other by the Tukey test ( $<<0.05)$.

For the combining ability analysis the diallel model used is represented below (Geraldi \& Miranda Filho, 1988), this model was adapted from the method two, model I of Griffing (1956), in which the parents are included in the analysis and the experimental material is considered a fixed set of inbred lines.

$Y_{i j}=\mu+1 / 2\left(d_{1}+d_{2}\right)+g_{i}+g_{j}+s_{i j}+\varepsilon_{i j}$

Where: $\mathrm{Y}_{\mathrm{ij}}=$ mean of the crossing involving the $i^{\text {th }}$ parent of group I and the $\mathrm{j}^{\text {th }}$ parent of group $\mathrm{II} ; \mu=$ overall mean of the diallel; $\mathrm{d}_{1}, \mathrm{~d}_{2}=$ contrasts involving the means of the groups I and II and the overall mean; $\mathrm{g}_{\mathrm{i}}=$ effect of the general combining ability of the $i^{\text {th }}$ genitor of group $\mathrm{I} ; \mathrm{g}_{\mathrm{j}}=$ effect of the general combining ability of the $\mathrm{j}^{\text {th }}$ genitor of 
group II; $s_{i j}=$ effect of the specific combining ability; $\varepsilon_{\mathrm{ijk}}=$ mean experimental error.

The severity of the disease was evaluated according to the scale of notes proposed by Ullasa et al. (1981), in which:

1 - resistant plant, no symptoms (R);

2 - moderately resistant plant, with up to $10 \%$ of the leaf area affected (MR);

3 - moderately susceptible plant, with $11-20 \%$ of the leaf area affected (MS);

4 - susceptible plant, with $21-50 \%$ of the leaf area affected (S);

5 - highly susceptible plant, with $51 \%$ or more of the leaf area affected (AS).

All statistical analysis was made through the program Genes, version 2007 (Cruz, 2006).

\section{RESULTS AND DISCUSSION}

Within the parents, the reactions of 'HV-12' and '\#124', used as source of resistance to the pathogen, was, respectively, resistant with average score 1 and moderately resistant with average score 1.86 (Table 1). These results corroborate with those obtained by Blat et al. (2005a, 2005b). The commercial hybrids used as female parents were highly susceptible. The triple hybrids obtained by crosses between the parents, presented an intermediate profile, highlighting the combinations 'Quantum-R x HV-12', 'Quantum-Rx\#124' and 'Rubia-Rx\#124', that were moderately susceptible to powdery mildew, with the respective average score 3.23, 3.37 and 3.45 (Table 1). According to Daubeze et al. (1995), the delay on the expression of the susceptibility suggests that the expression of the resistant genes is incomplete or partial and that it depends on a secondary infection. An early breeding evaluation can reveal phenotypes with intermediate reactions, but only an advanced breeding evaluation can detect and identify highly resistant genotypes like 'HV-12'(Blat, 2004).

The mean squares of the treatments were significant by $\mathrm{F}$ test $(\mathrm{P}<0.01)$ for all characteristics. In general, in these types of analysis, significant mean squares are evidence of the occurrence

Table 1. Severity notes of the disease and reaction of the parents and triple hybrids of sweet pepper to Oidiopsis taurica under protected cultivation (nota de severidade da doença e reação de genitores e híbridos triplos de pimentão a Oidiopsis taurica sob condições de ambiente protegido). Campinas, IAC, Brazil, 2007.

\begin{tabular}{|c|c|c|}
\hline Parent & Score & Reaction to pathogen $\left({ }^{*}\right)$ \\
\hline HV-12 & $1,00 \mathrm{a}$ & $\mathrm{R}$ \\
\hline \#124 & $1,86 \mathrm{~b}$ & MR \\
\hline Quantum-R & $4,98 \mathrm{~g}$ & AS \\
\hline Rubia-R & $4,95 \mathrm{~g}$ & AS \\
\hline Platero & $5,00 \mathrm{~g}$ & AS \\
\hline Margarita & $4,98 \mathrm{~g}$ & AS \\
\hline P36-R & $4,96 \mathrm{~g}$ & AS \\
\hline \multicolumn{3}{|l|}{ Triple hybrid } \\
\hline Quantum-R x HV-12 & $3,23 \mathrm{c}$ & MS \\
\hline Rubia-R x HV-12 & $3,63 d$ & $S$ \\
\hline Platero x HV-12 & $3,90 \mathrm{e}$ & $S$ \\
\hline Margarita x HV-12 & $3,69 d$ & S \\
\hline P36-R x HV-12 & $4,19 \mathrm{f}$ & $\mathrm{S}$ \\
\hline Quantum-R x \#124 & $3,37 \mathrm{c}$ & MS \\
\hline Rubia-R x \#124 & $3,45 c$ & MS \\
\hline Platero x \#124 & 3,88 e & $\mathrm{S}$ \\
\hline Margarita x \#124 & 3,94 e & S \\
\hline P36-R x \#124 & $4,00 \mathrm{e}$ & $S$ \\
\hline
\end{tabular}

* $\mathrm{R}=$ resistant $; \mathrm{MR}=$ moderately resistant; $\mathrm{MS}=$ moderately susceptible; $\mathrm{S}=$ susceptible; $\mathrm{AS}=$ highly susceptible; The means followed by the same letters are not significantly different among themselves by Tukey at $5 \%$.

of genetic variation between treatments, which allows obtaining satisfactory estimates of genetic parameters. There was a good experimental precision, demonstrated by the coefficients of variation, whose values were below $10 \%$ for most characters studied.

Considering the significance of the $F$ test, observed in the analysis of variance, the sum of squares of the treatments were unfolded into sum of squares for general combining ability (GCA) (groups I and II), and specific combining ability (SCA), as the model proposed by Geraldi \& Miranda Filho (1988), adapted from method two and model I of Griffing (1956), in which the parents are included in the analysis and experimental material is considered a fixed set of lines. This method was chosen because, for selfpollinated specie like pepper, it is of considerable interest to evaluate the performance of the hybrids, using the parents' lines as default.

The mean squares values for treatments, groups, GCA of group II and SCA were highly significant for all characters evaluated, except for wall thickness, which was not significant for SCA. For the GCA of group I, the characters weight and width average of the fruit, wall thickness and severity of the disease were significant at $1 \%$, and length average of the fruit and length and width ratio of the fruit were significant at $5 \%$ by $\mathrm{F}$ test. The significance of the mean square for GCA and SCA indicates that both, additive and non-additive genetic effects are involved in the control of all characters, except for SCA in relation to wall thickness that was not significant. The results suggest the possibility of obtaining new hybrids from the experimental material used, having in view the availability of additive and nonadditive variability for all the components evaluated.

An important fact that should be observed is related to the magnitude of the mean squares of GCA and SCA, showing that for all characters analyzed, the GCA of group II was higher than the SCA, showing a large contribution of 
Table 2. Estimates of the effects of the general combining ability of the group I for six characters of the fruits from five genotypes of sweet pepper used as female parents (estimativas dos efeitos da capacidade geral de combinação (CGC) do grupo I relativas a seis caracteres de frutos de cinco genótipos de pimentão utilizados como genitores femininos). Campinas, IAC, Brazil, 2007.

\begin{tabular}{|c|c|c|c|c|c|c|}
\hline \multirow{2}{*}{ Parent } & \multicolumn{6}{|c|}{ Character(*) } \\
\hline & PF (g) & CF (cm) & LF (mm) & C/L & $\mathrm{EP}(\mathrm{mm})$ & SD \\
\hline Quantum-R $g_{(1)}$ & $-1,25$ & $-0,03$ & 0,46 & $-0,003$ & 0,03 & $-1,71$ \\
\hline Rubia-R $g_{(2)}$ & $-3,10$ & $-0,35$ & $-1,31$ & $-0,002$ & $-0,06$ & $-1,71$ \\
\hline Platero $\mathrm{g}_{(3)}$ & 1,35 & 0,14 & $-0,42$ & 0,007 & 0,15 & 1,05 \\
\hline Margarita $g_{(4)}$ & $-2,84$ & $-0,06$ & $-0,17$ & 0,002 & $-0,07$ & 1,12 \\
\hline P36-R g $g_{(5)}$ & 5,85 & 0,30 & 1,44 & $-0,003$ & $-0,05$ & 1,25 \\
\hline $\mathrm{DPg}_{(\mathrm{i})}$ & 1,65 & 0,13 & 0,35 & 0,002 & 0,03 & 0,03 \\
\hline
\end{tabular}

${ }^{*} \mathrm{PF}=$ weight average of the fruit, $\mathrm{CF}=$ length average of the fruit, $\mathrm{LF}=$ width average of the fruit, $\mathrm{C} / \mathrm{L}=$ length and width ratio of the fruit; $\mathrm{EP}=$ wall thickness; $\mathrm{SD}=$ severity of the disease; $\mathrm{DP}=$ standard deviation.

additive gene action in controlling the characters studied, and that, in the inheritance of these characters, the additive genetic effects are more important. Miranda et al. (1988), evaluating the combining ability of pepper in a diallel, observed significant difference for GCA and SCA for various characters of the fruit and plant. Gomide et al. (2003), evaluating the combining ability between inbred lines of pepper, observed that GCA was significant for all components of production, while the SCA was important only for total production. Ahmed et al. (2003), evaluating the gene action and the combining ability in pepper, verified the occurrence of only non-additive effects for weight and width average of the fruit, whereas in the present study, additive and non-additive effects were observed, demonstrating the occurrence of good GCA and SCA. For length average of the fruit and wall thickness, the same authors (Ahmed et al., 2003) determined the existence of additive and nonadditive effects. Similar results were observed in this work for length average of the fruit, but not for wall thickness, in which the SCA was not significant, in other words, there was only additive effect for this character. This variation between the results occurs because of the genetic variability existent between the genotypes.

Gopalakrishnan et al. (1987), analyzing the combining ability between peppers, also obtained significant GCA for weight, length and width average of the fruit and length and width ratio of the fruit. For the SCA, there was significance only for length average of the fruit. In another diallel cross, involving seven inbred lines of Serrano type of pepper, González et al. (2004) noted significance of GCA and SCA only for non-additive effects for weight, length and width average of the fruit.

A restriction that should be highlighted in this work refers to the fact that the genetic parameters were estimated from a single location and environment (year). This forbids the estimation of the effects of genotypeenvironment interaction. Thus, these effects were added to the effects of the combining ability and may cause changes in the estimation of GCA and SCA effects. Therefore, the extrapolations based on the results of this work should take this observation into account.

The choice of parents for the formation of segregating populations is crucial for achieving success in breeding programs, and the combining ability, with the presence of complementary genes, being the responsible for the success. According to Miranda et al. (1988), parents who have high GCA should be preferred to constitute the blocks of crosses, favoring the selection of homozygous lines in self-pollinated species.
Estimates of the effects of GCA provide information on the concentration of genes with additive effects. Therefore, parents with high and positive GCA estimates are the main contributors to increase expression of the character, while those with high and negative values contribute to the reduction of its expression (Cruz \& Regazzi, 1997). For Cruz \& Vencovsky (1989), the greatest $g_{i}$ will be presented by the parent that has higher frequencies of favorable alleles for a given character. Therefore, these effects indicate the importance of predominantly additive effects (Sprague $\&$ Tatum, 1942). Thus, the parents with highest GCA will be the most favorable to be used in breeding programs, in which the goal is the selection of hybrids for agronomic characters or new inbred lines in advanced generations. For the selection of resistance to the pathogen, the opposite occurs, because the promising parents are those who have low or negative GCA effects, contributing to reducing the frequency of favorable alleles for the disease (Arabi, 2005).

The effects of GCA of group II were not analyzed because of the restriction of the model adopted, where the sum of $\mathrm{g}_{\mathrm{j}}$ equals zero.

For all the evaluated characters, which are of great importance in sweet pepper cropping for being linked to the quality of the fruit, it is possible to say that the effects of GCA of group I had different behavior between the commercial hybrids (Table 2).

The parents 'Platero' and 'P36-R' showed the largest magnitude of positive effects for GCA for weight average of the fruit and length average of the fruit contributing, respectively, with $\mathrm{g}_{\mathrm{i}}$ of $1.35 \mathrm{~g}$ and $0.14 \mathrm{~cm}$ for 'Platero' and $5.85 \mathrm{~g}$ and $0.30 \mathrm{~cm}$ for 'P36-R', in the crosses they participated in. The other parents had negative values of $g_{i}$ for both characters, in which the largest value was $-3.10 \mathrm{~g}$ for weight average of the fruit and $-0.35 \mathrm{~cm}$ for length average of the fruit, both values from 'Rubia-R', which helped to reduce the importance of these characters in the crosses it participated in. Regarding the GCA, González et al. (2004) in a diallel cross of 
different inbred lines of Serrano type of pepper; they obtained for the best parent, values of $0.9336 \mathrm{~g}$ and $0.5925 \mathrm{~cm}$, respectively, for weight and length average of the fruit.

For the character, width average of the fruit, the parent 'P36-R' had the highest positive estimate of $\mathrm{g}_{\mathrm{i}}$, contributing with an average increase of $1.44 \mathrm{~mm}$, followed by 'Quantum-R', with $0.46 \mathrm{~mm}$. The other female parents had negative effects, especially 'Rubia$\mathrm{R}$ ' with $\mathrm{g}_{\mathrm{i}}$ of $-1.31 \mathrm{~mm}$, leading to a decrease in the width average of the fruit in the crosses it participated in. Gopalakrishnan et al. (1987), evaluating the combining ability in pepper, observed positive effect of GCA for the genotype Jwala for weight, length and width average of the fruit, which stood out as the best combiner for these characters.

For the length and width ratio of the fruit, positive estimates were presented by 'Platero' (0.007) and 'Margarita' (0.002), although with very low values. In contrast, 'Quantum-R' and 'P36-R', presented the largest negative values, both with -0.003 .

As for the character wall thickness, 'Quantum-R' and 'Platero' showed the highest positive values, respectively, $0.03 \mathrm{~mm}$ and $0.15 \mathrm{~mm}$. The results show that these two parents are more suitable for the production of hybrids, in which the objective is to increase the wall thickness. The other parents had negative values, especially 'Margarita' with the largest negative contribution, which was $-0.07 \mathrm{~mm}$.

For the severity of the disease, the parents 'Quantum-R' and 'Rubia-R' presented negative estimates of $g_{i}$ with values of -0.016 and -0.009 , indicating that these parents contributed to reducing the severity of powdery mildew. The other female parents showed positive values, therefore, contributing to the increase of the disease.

Estimates of GCA of group I, for all genotypes and all the characters evaluated showed a large variation in the population used. This finding reflects the caution that the breeder should have in choosing the right parents for a breeding program,

Table 3. Estimates of the effects of the specific combining ability for five characters of the fruits from ten triple hybrids of sweet pepper (estimativas da capacidade específica de combinação (CEC) relativas a cinco caracteres dos frutos de dez híbridos triplos de pimentão). Campinas, IAC, Brazil, 2007.

\begin{tabular}{lccccc}
\hline \multirow{2}{*}{ Triple hybrid } & \multicolumn{5}{c}{ Character(*) } \\
\cline { 2 - 6 } & PF (g) & CF (cm) & LF (mm) & C/L & SD \\
\hline Quantum-R x HV-12 & $-3,48$ & 0,73 & 0,50 & 0,004 & $-0,36$ \\
Rubia- R x HV-12 & $-2,92$ & 0,31 & 1,64 & 0,019 & $-0,55$ \\
Platero x HV-12 & $-3,65$ & $-0,34$ & 0,40 & $-0,008$ & $-0,36$ \\
Margarita x HV-12 & $-10,55$ & $-0,60$ & $-1,04$ & 0,018 & $-0,55$ \\
P36-R x HV-12 & 8,80 & 0,62 & 1,78 & $-0,016$ & 0,11 \\
Quantum-R x\#124 & $-22,55$ & $-0,62$ & $-4,99$ & 0,019 & 0,05 \\
Rubia-R x\#124 & $-22,53$ & $-0,76$ & $-5,39$ & $-0,011$ & 0,43 \\
Platero x \#124 & $-25,09$ & $-1,00$ & $-5,56$ & 0,014 & 0,07 \\
Margarita x \#124 & $-17,64$ & $-0,59$ & $-4,56$ & $-0,006$ & 0,57 \\
P36-R x \#124 & $-27,26$ & $-0,99$ & $-5,45$ & 0,009 & 0,37 \\
\hline DP(sij) & 3,90 & 0,32 & 0,83 & 0,005 & 0,06 \\
\hline
\end{tabular}

" $\mathrm{PF}=$ weight average of the fruit, $\mathrm{CF}=$ length average of the fruit, $\mathrm{LF}=$ width average of the fruit, $\mathrm{C} / \mathrm{L}=$ length and width ratio of the fruit; $\mathrm{SD}=$ severity of the disease; $\mathrm{DP}=$ standard deviation.

especially when the intention is to improve several characters simultaneously. In practice, this is not always possible, as shown in Table 2, in which none of the genotypes showed good GCA for all the characters evaluated. The genotypes with higher GCA for the main characters of interest should be preferred.

In view of the results on Table 2 , the parents 'Platero' and 'P36-R' stood out as the best genotypes, due to the significant presence of additive genetic effects for most agronomic characters studied. For the continuity of the breeding program for resistance to $O$. taurica, it is recommended to use these two hybrids as recurrent parents in backcrosses, to recover the commercial characters of the triple hybrid, advancing six generations, without considering the possible need to backcross to the resistant parent. However, 'Quantum-R' and 'Rubia-R' are the most suitable parents to be used in a breeding program for the incorporation of resistance to powdery mildew, for having presented negative value of GCA.

The estimates of the SCA effects are found in Table 3. For the performance of the parents positive and negative values of $\mathrm{S}_{\mathrm{ij}}$ were observed for all characters studied. These results indicate the existence of bidirectional dominance deviations regulated by genes that increases the expression of the character and other genes, equally dominant that decreases. The effect of SCA is interpreted as a deviation of a hybrid in relation to what would be expected based on the GCA of its parents. Therefore, the most favorable hybrid should be the one with highest estimates of the SCA, in which one of the parents had the highest GCA (Cruz \& Vencovsky, 1989, Gomes et al., 2000). According to Gomes et al. (2000), the highest values are for the most dissimilar genotypes in relation to frequencies of genes with dominance, although they are also influenced by the low gene frequency average of the diallel.

The results of SCA for weight average of the fruit, showed that only the hybrid 'P36-R x HV-12' stood out with a value equal to $8.80 \mathrm{~g}$, whose female parent was considered a good general combiner, with the highest positive estimate for GCA (Table 2). However, when the hybrid 'P36-R' was crossed with pepper '\#124', the same parent showed the highest negative value of SCA (-27.26 g), indicating the action of genes that reduced the expression of the character (Table 3). According to Cruz \& Vencovsky (1989), parents that produces $\mathrm{F}_{1}$ hybrids with low SCA 
values indicate that based on GCA they are behaving as expected. On the other hand, high values, positive or negative, shows that some specific combinations behaved better or worse than expected. Therefore, the SCA is in large part, dependent on genes that show effects of dominance or epistasis, in other words, it highlights the importance of genes with non-additive effects, emphasizing the importance of nonadditive interactions, resulting from gene complementation between the parents.

The combination 'Quantum-R x HV12 ' had the maximum value of SCA $(0.73$ $\mathrm{cm}$ ) for length average of the fruit, followed by the triple hybrids 'P36-R $\mathrm{x}$ HV-12' and 'Rubia-R x HV-12', with SCA values of $0.62 \mathrm{~cm}$ and $0.31 \mathrm{~cm}$, respectively (Table 3 ). It is noteworthy that parents 'Quantum-R' and 'Rubia-R' had negative effects for GCA (Table 2), indicating that for these combinations, the non-additive gene effects were more important, and gene complementation occurred between the parents. These divergent results are common, and occurred also in the work of Souza (2007), who obtained negative value of GCA for some parents used in the production of hybrids of tomato and positive SCA for number of fruit per plant, fruit width, fruit wall thickness and total acid title. The same happened to some characteristics of pepper evaluated by Miranda et al. (1988).

For width average of the fruit, the triple hybrids 'P36-R x HV-12' and 'Rubia-R x HV-12' showed the highest values of SCA, respectively, $1.78 \mathrm{~mm}$ and $1.64 \mathrm{~mm}$, followed by 'Quantum-R x HV-12' (0.50 mm) and 'Platero x HV-12' $(0.40 \mathrm{~mm})$ (Table 3$)$. For this character, the parents 'Rubia-R' and 'Platero' behaved contrary to expected, since they presented negative GCA (Table 2), indicating that in these combinations, non-additive interactions were more important, in result of gene complementation between the parents, supporting the theory of Sprague \& Tatum (1942) and Cruz \& Regazzi (1997).

The highest positive values of SCA for length and width ratio of the fruit were observed in the triple hybrids 'Rubia-R x HV-12' and 'Quantum-R x $\# 124$ ', both with average of 0.019 , followed by 'Margarita x HV-12' (0.018), 'Platero x \#124' (0.014), 'P36-R x \#124' (0.009) and 'Quantum-R x HV-12' (0.004). The other triple hybrids showed negative SCA (Table 3). According to Miranda et al. (1988), the demand of the Brazilian market for length and width ratio of the fruit should be between 1.75 and 2.00. For these authors, the best combination would be the hybrid produced from the parent with greater GCA effect for length average of the fruit with the parent with the highest GCA effect for width average of the fruit, but in their work, this "ideal hybrid" presented low estimate of SCA effect.

Another restriction to be made in the evaluation of the length and width ratio of the fruit is related to the meaning of the positive value of SCA. It means that the triple hybrids showed a bigger ratio between these characters than their parents did before the cross. However, in this study, the triple hybrids did not achieve the commercial standard, because they were obtained by crosses with a pepper ('\#124') and a sweet pepper ('HV-12'), whose fruits have no commercial value. While there has been a gain for this character, the fruits are still small, having to be backcrossed to recover the size. Therefore, this index should be followed by the estimates of SCA for the length and width average of the fruit.

The results of SCA for wall thickness were not discussed because this feature was not significant at $5 \%$ by the F test, of the analysis of variance of the partial diallel.

For the severity of the disease, the triple hybrid with positive estimates of $\mathrm{S}_{\mathrm{ij}}$ were 'P36-R x HV-12', 'Quantum-R x \#124', 'Rubia-R x \#124', 'Platero x \#124', 'Margarita $x$ \#124' and 'P36-R x \#124', indicating the importance of genes with dominant or epistatic effects (Table 3 ). The results agree with the statements of Blat et al. (2005b), Shifriss et al. (1992) and Daubeze et al. (1995), which define the inheritance of the reaction of $C$. annuum to powdery mildew as polygenic, due to at least four pairs of recessive genes with dominant and epistatic effects, which effects act in a negative form if the objective is the exploitation of hybrids.
Regarding the incorporation of resistance, the triple hybrid that stood out for SCA were those whose parents were 'Quantum-R' and 'Rubia-R'; that occurred because these two genotypes showed negative GCA for severity of the disease, contributing to the reduction of the disease (Table 2). Linking Table 1 with Table 3 note that the triple hybrids obtained from crosses with 'Quantum$R$ ' and 'Rubia- $R$ ' had the best reactions to powdery mildew except for 'QuantumR x HV-12'.

In regard to agronomic characters it can be affirmed that, in general, all triple hybrids crossed with the pepper '\#124', showed negative SCA for all characters evaluated, except for length and width ratio of the fruit, which must be considered with restriction, as discussed above. The hybrid 'P36-R x HV-12' showed positive SCA effect for the characters weight, length and width average of the fruit and severity of the disease. The good performance of 'P36$\mathrm{R}$ ' was expected, for it was considered one of the best combiners by the estimates of GCA. The triple hybrids 'Quantum-R x HV-12' and 'Rubia-R x HV12 ' had the opposite SCA effect of what was expected, according to its GCA there was greater influence of non-additive genes effects in these combinations, highlighting them as highly potential hybrids, together with 'P36-R x HV-12'. 'Platero' was considered a good combiner by its GCA, but had opposite effect when used in hybridizations. Miranda et al. (1988) obtained similar results for the character number of fruits per plant. In the two crosses in which it participated ('Platero $\mathrm{x} \mathrm{HV-12'} \mathrm{and}$ 'Platero $x$ \#124') the SCA was negative for all characters, except for width average of the fruit when crossed with 'HV-12', indicating that for 'Platero', the additive genetic effects had greater influence on the studied characters.

For the conditions under which the work was done, it is possible to conclude that for most characters evaluated, the additive and non-additive effects were important and significant, however, the additive effects of group II were higher than the non-additive effects for all agronomic characters evaluated; the sweet peppers 'P36-R' and 'Platero' were 
highlighted as good combiners for presenting greater GCA for most agronomic characters evaluated; the triple hybrid 'Quantum-R x HV-12', 'Rubia-R x HV-12' and 'P36-R x HV-12' were highlighted as the best performance among all genotypes for agronomic characters with the best SCA; triple hybrids obtained from crosses with 'Quantum-R' and 'Rubia$\mathrm{R}$ ' presented a negative GCA and the best reactions to powdery mildew.

\section{REFERENCES}

AGRIANUAL - Anuário da Agricultura Brasileira. 2008. Pimentão. São Paulo: FNP Consultoria \& Comércio. p.435-437.

AHMED N; HURRA M; WANI SA; KHAN SH. 2003. Gene action and combining ability for fruit yield and its component characters in sweet pepper. Capsicum and Eggplant Newsletter 22: 55-58.

ARABI MIE. 2005. Diallel analysis of barley for resistance to leaf stripe and impact of the disease on genetic variability for yield components. Euphytica 145: 161-170.

BERGAMIN FILHO A; KIMATI H; AMORIM L. 1995. Manual de fitopatologia: princípios e conceitos. 3 ed. São Paulo: Ceres, v.1, 919 p.

BETTIOL W; GARIBALDI A; MIGHELI Q. 1997. Controle do oídio do pepino e da abóbora com Bacillus subtilis. Bragantia 56: 281-287.

BLAT, SF. 2004. Herança da reação de Capsicum spp. ao oídio (Leveillula taurica (LÉV.) ARN.). Piracicaba: USP - ESALQ. 153p. (Tese doutorado).

BLAT SF; COSTA CP; VENCOVSKY R; SALA FC. 2005a. Reação de acessos de pimentão e pimentas ao oídio (Oidiopsis taurica). Horticultura Brasileira 23: 72-75.

BLAT SF; COSTA CP; VENCOVSKY R; SALA FC. 2005b. Inheritance of reaction to Leveillula taurica (Lev.) Arn. in Capsicum annuum L. Sciencia Agrícola 62: 40-44.

BOITEUX LS, SANTOS JRM; LOPES CA. 1994. First record of powdery mildew of sweet-pepper Capsicum annuum incited by Leveillula taurica in Brazil. Fitopatologia Brasileira, 19: 304. (Resumo)
CARVALHO SIC; BIANCHETTI LB; HENZ GP. 2003. Germplasm collection of Capsicum spp. maintained by Embrapa Hortaliças (CNPH). Capsicum and Eggplant Newsletter 22: 17-20.

CRUZ CD. 2006. Programa Genes: estatística experimental e matrizes. Viçosa: UFV. $285 \mathrm{p}$.

CRUZ CD; REGAZZI AJ. 1997. Modelos biométricos aplicados ao melhoramento genético. Viçosa: UFV. 390p.

CRUZ CD; VENCOVSKY R. 1989. Comparação de alguns métodos de análise dialélica. Revista Brasileira de Genética 12: 425-438.

DAUBEZE AM; HENNART JW; PALLOIX A. 1995. Resistance to Leveillula taurica in pepper (Capsicum annuum) is ligogenically controlled and stable in Mediterranean regions. Plant Breeding 114: 327-332. (CD-ROM).

EMBRAPA HORTALIÇAS. 2008, 23 de setembro. Hortaliças em números - dados sócio-econômicos. Disponível em http:// www.cnph.embrapa.br/util/tabelas/ index.htm.

GERALDI IO; MIRANDA FILHO JB. 1988. Adapted models for the analysis of combining ability of varieties in partial diallel crosses. Revista Brasileira de Genética 11: 419-430.

GOMES MS; PINHO EVRV; PINHO RGV; VIEIRA MGGC. 2000. Estimativas da capacidade de combinação de linhagens de milho tropical para qualidade fisiológica de sementes. Ciência e Agrotecnologia 24: 4149.

GOMIDE ML; MALUF WR; GOMES LAA. 2003. Heterose e capacidade combinatória de linhagens de pimentão (Capsicum annuum L.). Ciência e Agrotecnologia 27: 1007-1015.

GONZÁLEZ JRAD; ZAMBRANO GM; MERAZ MR; LOERA AR; CAMPODÓNICO OP. 2004. Efectos genéticos y heterosis de caracteres de calidad comercial en chile Serrano. In: CONVENCIÓN MUNDIAL DEL CHILE, 1. Memorias... León: CONAPROCH. p.2128. Disponível em http://www.worldpepper.org/2004/memorias $2004 /$ 21_dorantes_gonzalez_wpc2004.pdf

GOPALAKRISHNAN TR; GOPALAKRISHNAN PK; PETER KV. 1987. Heterosis and combining ability analysis in chilli. Indian Journal of Genetics 47: 205-209.
GRIFFING B. 1956. Concept of general and specific ability in relation to diallel crossing systems. Australian Journal of Biological Sciences 9: 462-93.

IEA - Instituto de Economia Agrícola. Informações estatísticas da agricultura. 2008, 23 de setembro. Disponível em http:/ /www.iea.sp.gov.br/out/anuario.php.

MALUF WR. 2001. Heterose e emprego de híbridos $F_{1}$ em hortaliças. In: NASS, LL; VALOIS ACC; MELO IS; VALADARESINGLIS MC. (eds) Recursos genéticos e melhoramento: plantas. Rondonópolis: Fundação MT, p. 327-355.

MIRANDA JEC; COSTA CP; CRUZ CD. 1988. Análise dialélica em pimentão. I. Capacidade combinatória. Revista Brasileira de Genética 11: 431-440.

REIS A; BOITEUX LS; PAZ-LIMA ML; SILVA PP; LOPES CA. 2004. Powdery mildew of Allium species caused by Oidiopsis taurica in Brazil. Horticultura Brasileira 22: 758760 .

REIS A; BOITEUX LS; LOPES CA; HENZ GP. 2005. Oidiopsis haplophylli (Leveillula taurica): um patógeno polífago e amplamente distribuído no Brasil. Brasília: Embrapa Hortaliças, 13p. (Embrapa Hortaliças. Comunicado Técnico, 26).

REIS A; BOITEUX LS; PAZ-LIMA ML. 2007. Oídio em plantas ornamentais, causado por Oidiopsis haplophylli, no Brasil. Summa Phytopathologica 33: 405-408.

SHIFRISS C; PILOWSKY M; ZACKS JM. 1992. Resistance to Leveillula taurica mildew (=Oidiopsis taurica) in Capsicum annuum. Phytoparasitica 20: 279-283.

SOUZA LM. 2007. Cruzamentos dialélicos entre genótipos de tomate de mesa. Campinas: IAC. 61p (Tese mestrado).

SOUZA VL; CAFÉ-FILHO AC. 2003. Resistance to Leveillula taurica in genus Capsicum. Plant Pathology 52: 613-619.

SPRAGUE GF; TATUM LA. 1942. General vs. specific combining ability in single crosses of corn. Journal of the American Society of Agronomy 34: 923-932.

STADNIK MJ. 2001. História e taxonomia de oídios. In: STADNIK, MJ; RIVERA, MC. (eds) Oídios. Jaguariúna: Embrapa Meio Ambiente, p.3-30.

ULLASA BA; RAWAL RD; SOHI HS; SINGH DP. 1981. Reaction of sweet pepper genotypes to anthracnose, cercospora leaf spot and powdery mildew. Plant Disease 65: 600-601. 